\title{
Erratum: An Optimized Approach to Recover Secreted Proteins from Fibroblast Conditioned-Media for Secretomic Analysis
}

\author{
Frontiers Production Office * \\ Frontiers Production Office, Frontiers, Switzerland
}

Keywords: secretomic, 2D-DIGE, secreted proteins, secretome, fibrolast-conditioned media

\section{An erratum on}

OPEN ACCESS

Approved by:

Cellular Neuroscience Editorial Office,

Switzerland

*Correspondence:

Frontiers Production Office production.office@frontiersin.org

Received: 11 April 2016 Accepted: 11 April 2016

Published: 25 April 2016

Citation:

Frontiers Production Office (2016) Erratum: An Optimized Approach to

Recover Secreted Proteins from Fibroblast Conditioned-Media for

Secretomic Analysis. Front. Cell. Neurosci. 10:107. doi: 10.3389/fncel.2016.00107
An Optimized Approach to Recover Secreted Proteins from Fibroblast Conditioned-Media for Secretomic Analysis

by Paré, B., Deschênes, L. T., Pouliot, R., Dupré, N., and Gros-Louis, F. (2016). Front. Cell. Neurosci. 10:70. doi: 10.3389/fncel.2016.00070

Reason for Erratum:

Due to a typesetting error, a misalignment in Table 2 lead to the publication of incorrect information. In the "Resolving gel" column, line "1.5M TRIS-HCl, $\mathrm{pH} 8.8$," the volume should be $4.5 \mathrm{~mL}$, and not $4.5 \mathrm{~L}$ as published.

The publisher apologizes for this error and the correct version of Table 2 appears below.

This error does not change the scientific conclusions of the article in any way.

Copyright $(2016$ Frontiers Production Office. This is an open-access article distributed under the terms of the Creative Commons Attribution License (CC BY). The use, distribution or reproduction in other forums is permitted, provided the original author(s) or licensor are credited and that the original publication in this journal is cited, in accordance with accepted academic practice. No use, distribution or reproduction is permitted which does not comply with these terms. 


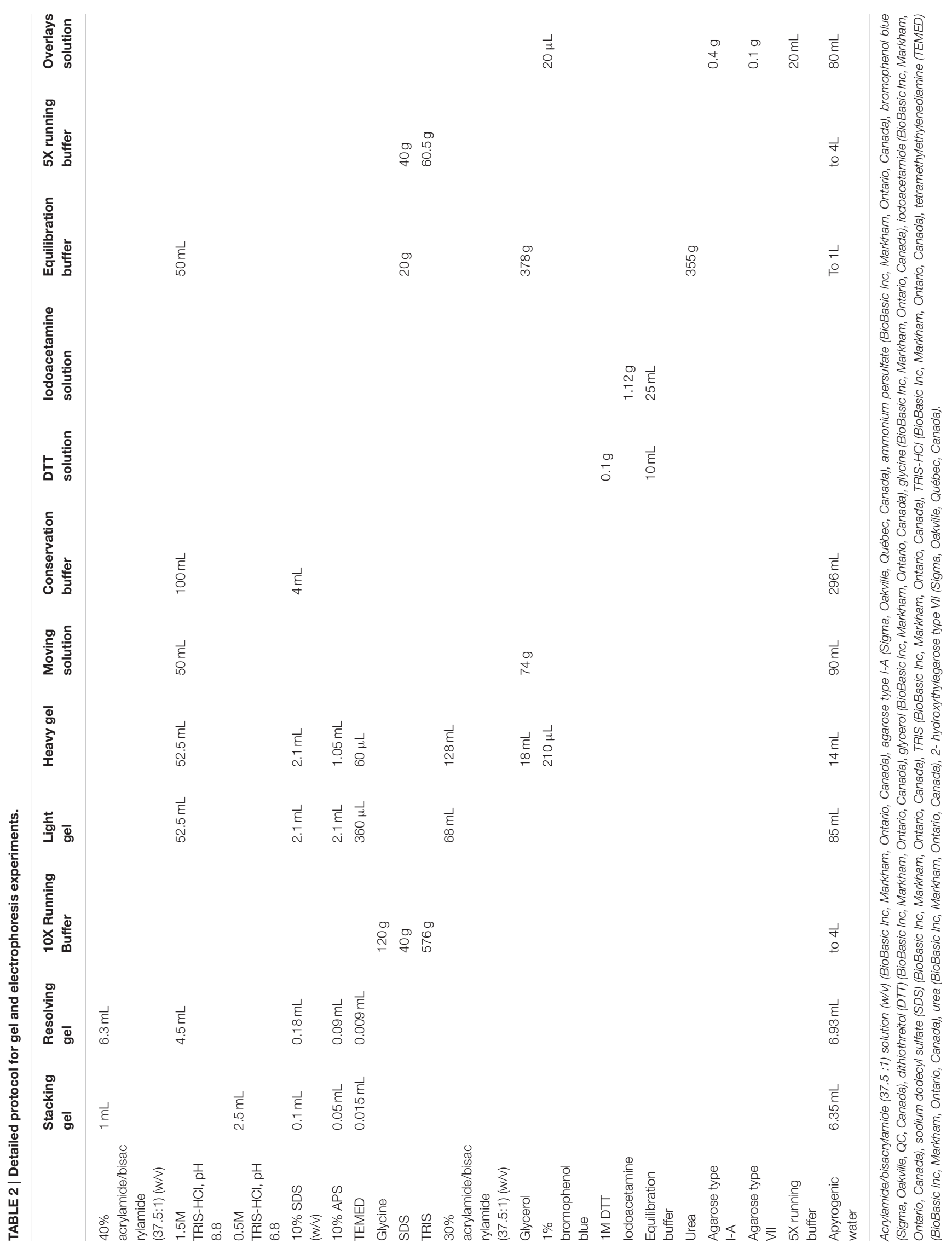

